by patients in the correspondence on this topic sent to the British Diabetic Association is that doctors may refuse to acknowledge that a particular patient is having continued problems with human insulin despite adjustments in dose. In some cases changing back to the insulin species with which the diabetes was previously stabilised-either porcine or bovine-has been shown to restore warning symptoms of hypoglycaemia. ${ }^{30}$ Doctors should, therefore, be aware of the risk of altered control, explain this risk to their patients (as well as the reasons for any changeover), and closely monitor the patient in the subsequent weeks. It is particularly necessary to warn patients of the danger of hypoglycaemia while driving and remind them of the need for checking blood glucose concentrations before the journey and at about two hourly intervals during long periods of driving. Doctors should take any adverse effects seriously and even be ready to change the patient back to animal insulin if necessary. Full ranges of both bovine and porcine insulins are still marketed in Britain. Finally, the British Licensing Authority has recently written to insulin manufacturers suggesting that the patient leaflets and the datasheets for human insulin should contain a specific warning that some patients have noted less pronounced symptoms of hypoglycaemia on transferring to human insulin from animal insulin. All insulin manufacturers have already made this change.

\section{JOHN PICKUP}

Reader,

Division of Chemical Pathology,

United Medical and Dental Schools of Guy's and

St Thomas's Hospitals,

Guy's Hospital,

London SE1 9RT
1 Pickup JC. Human insulin. Br.Med f 1986;292:155-7.

2 Berger AS, Saurbrey N, Kuhl C, Villunsen J. Clinical experience with a new device that will simplify insulin injections. Diabetes Care 1985;8:73-6.

3 Teuscher A, Berger WG. Hypoglycaemia unawareness in diabetics transferred from beef/porcin insulin to human insulin. Lancet 1987;ii:382-5.

4 Sussman KE, Crout JR, Marble A. Failure of warning in insulin-induced hypoglycemic reactions. Diabetes 1963;12:38-45

5 Heller SR, MacDonald IA, Herbert M, Tattersall RB. Influence of sympathetic nervous system on hypoglycaemic warning symptoms. Lancet 1987;ii:359-63.

6 Maddock SJ, Trimble HC. Prolonged insulin hypoglycemia without symptoms. FAMA 1928;91 616-21.

Balodimos MC, Root HF. Hypoglycemic insulin reactions without warning symptoms. FAMA 1959;171:261-6.

8 Berger W, Keller U, Honegger B, Jaeggi E. Warning symptoms of hypoglycaemia during treatment with human and porcine insulin in diabetes mellitus. Lancet 1989;i:1041-4

9 Hepburn DA, Frier BM. Hypoglycaemic unawareness and human insulin. Lancet 1989;i:1394

10 Muhlhauser I, Berger M. Hypoglycaemic unawareness and human insulin. Lancet 1989;i: 1394-5.

11 Kerr D, MacDonald I, Hillier J, Tattersall R. Adrenaline responses to hypoglycaemia and insulin species. Lancet 1989;i:836.

12 Turner TA, O'Mullane NM, Sivner A, Healey M, Walter D. Switching to human insulin. Lancet 1988;ii:1150.

13 Redmond S. Changing to human insulin. Balance 1988 Aug/Sept:66-7.

14 Peacock I, Tattersall RD, Taylor A, Douglas CA, Reeves WG. Effects of new insulins on insulin and C-peptide antibodies, insulin dose, and diabetic control. Lancet 1983;i:149-52.

15 Gill GV, Jones KE. Beef to human insulin: dose for dose? Lancet 1988;i:1305.

16 Amiel SA, Tamborlane WV, Simonson DC, Sherwin RS. Defective glucose counterregulation afte strict glycemic control of insulin-dependent diabetes mellitus. N Engl f Med 1987;316:1376-83.

17 Amiel SA, Sherwin RS, Simonson DC, Tamborlane WV. Effect of intensive insulin therapy on glycemic thresholds for counterregulatory hormone release. Diabetes 1988;37:901-7.

18 Lager I, Attvall S, Blohme G, Smith U. Altered recognition of hypoglycemic symptoms in type 1 diabetes during intensified control with continuous subcutaneous insulin infusion. Diabetic Med $1986 ; 3: 322-5$

19 Berger M. Human insulin: much ado about hypoglycaemia (un)awareness. Diabetologia 1987;30: $829-33$

20 Clark AJL, Adeniyi-Jones RO, Knight G, et al. Biosynthetic human insulin in the treatment of diabetes. Lancet 1982;ii:354-7.

21 Mann NP, Johnston DI, Reeves WG, Murphy MA. Human insulin and porcine insulin in the treatment of diabetic children: comparison of metabolic control and insulin antibody production. BrMed f 1983;287:1580-2.

22 Home PD, Mann NP, Hutchinson AS, et al. A fifteen month double-blind cross-over study of the efficacy and antigenicity of human and pork insulins. Diabetic Med 1984;1:93-8.

23 Landgraf-Leurs MMC, Brugelmann I, Kammerer S, Lorenz R, Landgraf R. Counterregulatory hormone release after human and porcine insulin in healthy subjects and patients with pituitary disorders. Klin Wochenschr 1984;62:695-8.

24 Owens DR, Vora JP, Tronier B, Keller U, Luzio S, Turkes A. Hormonal counterregulatory responses to human (semi-synthetic and recombinant DNA) and porcine insulin induced hypoglycaemia. Diabetes Res 1988:8:17-20.

25 Hepburn DA. Patrick AW, Eadington DW, Colledge N, Frier BM. How common are changes in hypoglycaemic awareness after conversion from animal to human insulins? Diabetic Med 1988;5( (suppl 2):7.

26 Gulan M, Perlman K, Sole M, Albisser AM, Zinman B. Counterregulatory hormone responses preserved after long-term intravenous insulin infusion compared to continuous subcutaneous insulin infusion. Diabetes 1988:37.526-31.

27 Kerr D, MacDonald IA, Tattersall RB. Adaptation to mild hypoglycaemia in normal subjects despite sustained increases in counter-regulatory hormones. Diabetologia 1989;32:249-54.

28 Binder C, Lauritzen T, Faber $O$, Pramming S. Insulin pharmacokinetics. Diabetes Care 1984;7:188-99.

29 Ziel FH, Davidson MB, Harris MD, Rosenburg CS. The variability in the action of unmodified insulin is more dependent on changes in tissue insulin sensitivity than on insulin absorption. Diabetic Med 1989;5:662-6.

30 Teuscher A, Egger M. Human insulin hypoglycaemia unawareness. Lancel 1989;i:1072.

\title{
Risk taking
}

\section{A need for perspective}

In midsummer the House of Commons Social Services Committee criticised the government for being slow in issuing information on food hygiene. Pregnant women could have been alerted to the hazards of listeria earlier, said the committee. These charges - and new proposals for improving food hygiene-are due to be debated when parliament reassembles. The committee was forthright in its criticism. But did it appreciate the problems in issuing public warnings? We are surrounded by risks, some of which are hard to ascertain, let alone set in perspective.

The doctor talking to an individual patient may find the question "What are the risks?" - for all its apparent simplicity - hard to answer. If he minimises the risks to spare a nervous patient anxiety then dissatisfaction and even legal action may ensue. Yet if every risk is spelt out important benefits of treatment may be lost. There may be something of a cry from the heart in David Kerr's comment: "I hope I shall never be expected to explain to my hypertensive patients, already reluctant to take their drugs regularly, that there is a remote risk of heart failure, asthma, jaundice, diabetes, impotence, nightmares, motor accidents, gout, depression, and writer's block."

Difficult though it may be to inform and advise individual patients on complex issues, there are additional problems for those who have to issue general statements of advice to the public at large. There will always be people for whom general advice must be inappropriate. On any important matter, and perhaps particularly on health matters, any official statement is exposed at once to scrutiny by politicians and journalists, and both may wish to generate as much controversy and public noise as possible. The tone of the statement must be neither alarmist nor complacent, and it must be categorical, however uncertain the evidence underpinning it. It must also be made at the right time, neither a moment too soon nor a moment too late.

These difficulties are not always adequately recognised. The report of the social services committee on Food Poisoning: Listeria and Listeriosis asserted that "Too much information issued to the public on food safety and hygiene has come out in dribs and drabs. The Department of Health should have 
taken a more proactive stance."' Given that most knowledge comes "in dribs and drabs," why should information not be given out in this way: or should the department always wait until each issue is completely clarified? I often mix my metaphors, but not I hope to the level of a "proactive stance." But if, as I believe, the committee was harsh in its criticism, it was soon outpaced by the media. The political correspondent of Today began his article on 30 June with the sentence, "Twenty six babies died because bungling health chiefs delayed a warning over deadly listeria for two years." One would scarcely suspect from that statement that listeria is commonly found in food, that many of us are carriers, and that there is much still to be learnt about the problems posed by this organism.

DOUGLAS BLACK

Whitchurch on Thames,

Reading RH8 7EN

1 Kerr DNS. Costs of safe medicine. $\mathcal{F} R$ Coll Physicians Lond 1980;14:153-6.

2 House of Commons Social Services Committee. Sixth report. Food poisoning: listeria and listeriosis. London: HMSO, 1989.

\section{The search for safer cigarettes}

\section{Stopping smoking is still the answer}

Cigarette' smoking remains one of the most pressing health issues in the industrially developed countries. It contributes annually to more premature deaths than any other single cause. ${ }^{1}$ The public health policy in these countries is to encourage smokers to stop the habit and to discourage nonsmokers from starting. In Britain this has been relatively successful: compared with many other countries there has been a more rapid fall in the prevalence of smoking. ${ }^{2}$ Among men over the age of 20 , for example, the proportion smoking fell from $52 \%$ in 1974 to $35 \%$ in 1987 . Similar rates of decline in prevalence have been seen in women and in the 20-44 year olds - the important group for future health.

Most current smokers, however, find stopping very difficult. ${ }^{3}$ Some $80 \%$ of those who stop may be expected to develop a withdrawal syndrome. ${ }^{+}$While stopping should remain the target, might it be possible to lessen the health hazards of smoking for those who continue to smoke?s

The composition of tobacco smoke has altered greatly over the past 40 years as a result of changes in the manufacture of cigarettes. These changes have added impetus to the quest for less hazardous smoking. Firstly, filters were introduced, becoming popular in the 1950 s. Few people now smoke plain cigarettes. ${ }^{6}$ Filters remove particles, the so called tar, from the smoke together with some of the nicotine, which is found within the tar fraction. ${ }^{7}$ Further reductions in tar and nicotine yields have occurred as a result of a wide range of techniques called "cigarette engineering," which have also altered carbon monoxide yields. ${ }^{8}$

The health consequences of changes in the manufacture of cigarettes have been difficult to predict. This reflects both the chemical complexity of tobacco smoke, which contains over 4000 constituents, ${ }^{9}$ and the lack of knowledge of the factors that cause and promote disease. A lot of research has been done, however, on the effects of past reductions in tar, nicotine, and carbon monoxide yields of cigarettes on the prevalence of disease among smokers. Even this approach has not been without problems. ${ }^{10}$

Cigarette smokers are able to regulate their smoking behaviour so as to maintain their body nicotine concentrations within close limits. ${ }^{11}$ In general, a reduction in the tar yield of a cigarette is associated with a fall in its nicotine yield. ${ }^{12}$ Not surprisingly, therefore, when smokers switch from high to low yield cigarettes they often compensate by smoking more. ${ }^{13-15}$ They may simply smoke more cigarettes a day ${ }^{16}$; but-unlike laboratory analytical smoking machinessmokers may also vary the frequency and volume of puffing and so increase the yield from each cigarette. Alterations in the depth of inhalation may also influence the uptake of constituents of cigarette smoke. ${ }^{17}$ Nevertheless, the average smoker's compensation for reduced nicotine yields seems incomplete. Indices of exposure to $\operatorname{tar}^{1+}$ and gaseous components of smoke $^{18}$ seem to be lower when smokers switch from high to low yield cigarettes.

The effects of changes in cigarettes on disease are in line with these observations. Smokers of old style low $\operatorname{tar}(<22$ mg) filter cigarettes have a lower risk of lung cancer than smokers of old style high $\operatorname{tar}(>29 \mathrm{mg})$ non-filter cigarettes. ${ }^{19-21}$ The differences in risk are, however, small when compared with the effect of stopping - after 10-15 years former smokers have a similar risk of lung cancer to that of lifelong nonsmokers. ${ }^{22}$ The benefit of switching from non-filter to filter cigarettes is lost if smokers compensate by increasing daily cigarette consumption. ${ }^{23}$ There are no substantial data that compare modern low tar $(<10 \mathrm{mg})$ cigarettes with the old fashioned cigarettes. The risk of developing lung cancer depends on the smoking history 15-20 years earlier, when few people used such cigarettes. ${ }^{6}$ So we do not yet know whether the recent reductions in yield will further reduce the risk of lung cancer.

For coronary heart disease evidence that filter (old style) cigarettes constitute less of a risk than non-filter cigarettes is less convincing than it is for lung cancer. ${ }^{102+25}$ Any benefit seems small and may be confined to people who consciously inhale smoke. ${ }^{19}$ In contrast to lung cancer, however, it has proved possible to study the health effects of contemporary cigarettes, as the risks of having a myocardial infarction decrease within two years of stopping smoking to a level similar to that in non-smokers. ${ }^{26}$ This suggests that current smoking habit is an important determinant of risk of coronary artery disease. Studies in both men and women have shown that contemporary low tar and nicotine cigarettes do not lessen the risks of myocardial infarction. ${ }^{27}{ }^{28}$ These studies confirmed earlier reports ${ }^{29}$ in showing no increased risk associated with a raised carbon monoxide yield.

For chronic bronchitis and emphysema again the picture is unclear. Old style non-filter cigarettes are associated with increased production of phlegm ${ }^{30}$ and possibly more severe airway obstruction. ${ }^{30-32}$ There is no information on contemporary cigarettes, however, as again the development of airway disease seems to depend on smoking habits $10-15$ years earlier. ${ }^{30}$

From these recent observations we may perhaps conclude that there are some benefits from smoking filter (old style) rather than non-filter, high tar and nicotine cigarettes. These benefits are much smaller, however, than those of stopping the habit, and they may be negated by increases in daily cigarette consumption. The information on health hazards of contemporary cigarettes remains incomplete, but we are a 